\title{
Partial Characterization of Glycopeptides from Culture Filtrates of Fulvia fulva (Cooke) Ciferri (syn. Cladosporium fulvum), the Tomato Leaf Mould Pathogen
}

\author{
By J. M. DOW AND J. A. CALLOW \\ Department of Plant Sciences, Baines Wing, University of Leeds, Leeds LS2 9JT
}

(Received 27 September 1978)

\begin{abstract}
Culture filtrates of races 0,4 and 1.2.3. of Fulvia fulva were fractionated by sequential gel chromatography on Bio-Gel P-2, ion-exchange chromatography on DEAE-cellulose and affinity chromatography on concanavalin A-Sepharose 4B. The fractions were characterized for their carbohydrate, phosphate and protein contents and sugar compositions. D-Galactose, D-glucose and D-mannose were the major sugars with much smaller amounts of D-glucuronic acid, D-galactosamine and D-glucosamine. Phosphate was present as a diester. The carbohydrate was present in a family of glycopeptides of disperse molecular weight, charge and sugar composition. The molecular organization of these polymers was further investigated by mild acid and alkali degradation and by acetolysis of the polysaccharide remaining after these treatments. A possible structure for the polymers is suggested.
\end{abstract}

\section{INTRODUCTION}

All fungi synthesize and secrete polysaccharides and glycoproteins into their walls and growth media (Bartnicki-Garcia, 1968; Gander, 1974). Recently attention has been paid to the possible rôle of such polymers as elicitors of phytoalexin accumulation and determinants of specificity in host-phytopathogen interactions (Albersheim \& Anderson-Prouty, 1975; Keen, 1975; Ayers et al., 1976a,b,c; Callow, 1977; Stekoll \& West, 1978). In particular, polymers from culture filtrates of Fulvia fulva (syn. Cladosporium fulvum) have been suggested to have a rôle in the determination of specificity in the gene-for-gene interaction between this pathogen and the host tomato (Van Dijkman \& Kaars Sijpesteijn, 1971, 1973). The active moieties of these polymers are probably carbohydrate in nature (Dow \& Callow, 1979). In this paper, we report the characterization of glycopeptides from culture filtrates of three different races of $F$. fulva with particular reference to the carbohydrate moiety. This work is part of a series of investigations into the biochemical nature of varietal specificity in the $F$. fulva-tomato system. The possible rôle of these polymers in the host-pathogen interaction has been discussed elsewhere (Dow \& Callow, 1979).

\section{METHODS}

Growth of the organism. As a precaution against loss of pathogenicity, Fulvia fulva races 0,4 and 1.2.3. were maintained on potato-dextrose-agar medium at $4^{\circ} \mathrm{C}$ in the dark. Conidia were harvested from cultures grown at $24^{\circ} \mathrm{C}$ in the dark on potato-dextrose-agar. For labelling, fungi were grown in $125 \mathrm{ml}$ medium in 11 Erlenmeyer flasks. Two media were used: medium A contained (per litre) $10 \mathrm{~g}$ glycerol, $2 \mathrm{~g}$ Casamino acids, $1.5 \mathrm{~g} \mathrm{MgSO}_{4} .7 \mathrm{H}_{2} \mathrm{O}, 0.1 \mathrm{~g} \mathrm{KCl}, 2 \mathrm{mg} \mathrm{ZnCl} 2$ and $2 \mathrm{mg} \mathrm{MnSO}_{4} .4 \mathrm{H}_{2} \mathrm{O}$ in tap water buffered to pH 6.0 with 2.5 mM-phosphate buffer; medium B contained glucose $\left(2 \mathrm{~g}^{-1}\right)$ instead of glycerol. Medium A was designed to allow the exclusive labelling of carbohydrate from $\mathrm{D}-\left[\mathrm{U}-{ }^{14} \mathrm{C}\right] \mathrm{glucose}$ as described 


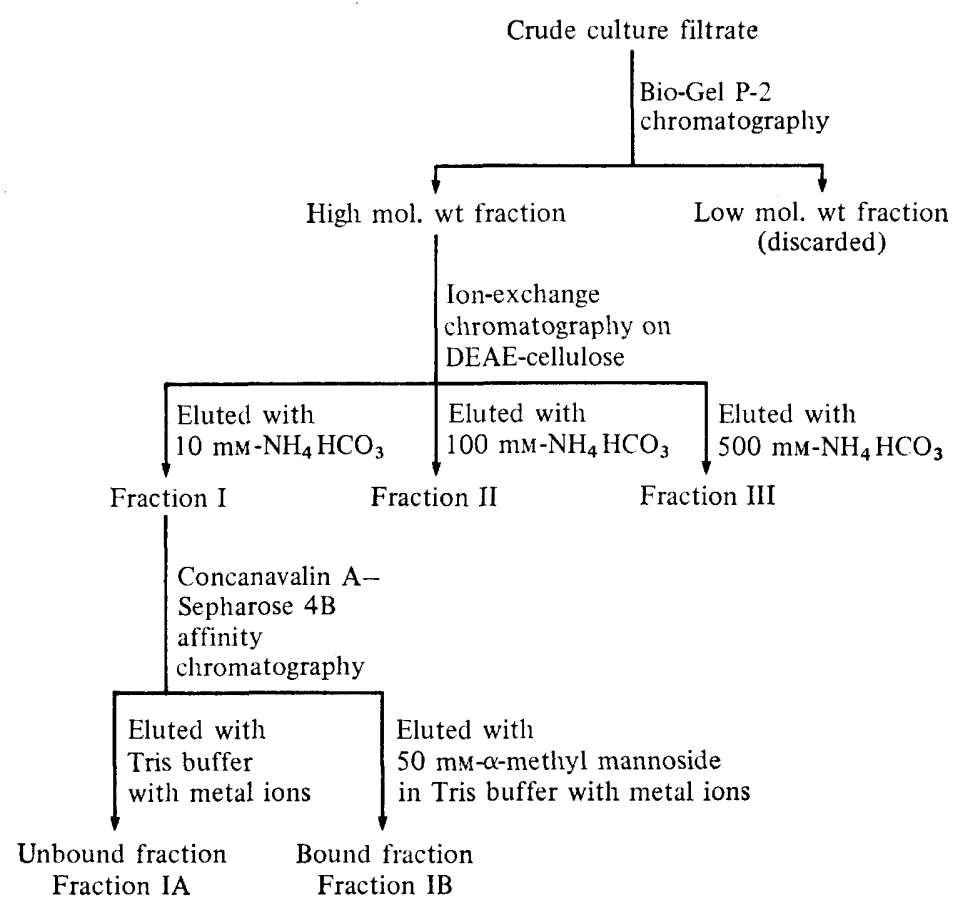

Fig. 1. Protocol for the fractionation of culture filtrates of Fulvia fulva.

previously (Dow \& Rubery, 1977). Media and flasks were sterilized together by autoclaving at $120^{\circ} \mathrm{C}$ for $20 \mathrm{~min}$. D-[U-14 $\mathrm{C}]$ Glucose was added through a presterilized Millipore filter $(0.22 \mu \mathrm{m}$ diam. pore $)$ before media were inoculated with a washed conidial suspension of the fungus to a final concentration of $10^{5} \mathrm{ml}^{-1}$. Flasks were shaken in an orbital incubator $\left(200 \mathrm{rev} . \mathrm{min}^{-1}\right)$ at $24^{\circ} \mathrm{C}$. Radiochemicals _were from, The Radiochemical Centre, Amersham.

Fractionation of culture filtrates. After $21 \mathrm{~d}$ growth, the fungus was removed from the culture fluid by passage through Whatman GF/A glass-fibre paper discs. Culture filtrates were fractionated sequentially by gel chromatography on Bio-Gel P-2, ion-exchange chromatography on DEAE-cellulose and affinity chromatography on concanavalin A-Sepharose 4B (see Fig. 1).

Hydrolysis conditions, electrophoresis and analytical methods. These were as described previously (Dow \& Rubery, 1977) except that acidic hydrolysates were neutralized with $\mathrm{BaCO}_{3}$.

Acetolysis of fractions. Acetolysis was carried out at $37^{\circ} \mathrm{C}$ for $16 \mathrm{~h}$ by the method of Stewart et al. (1968). De-acetylated oligosaccharides were dissolved in water and fractionated by gel filtration on a column of Bio-Gel P-2 (bed dimensions $2 \times 96 \mathrm{~cm}$ ).

Liquid scintillation spectrometry. Samples were prepared as described previously (Dow \& Rubery, 1977). Radioactivity was determined on a Unilux III liquid scintillation counter.

Other analytical procedures. Colorimetric estimation of sugars was done by the method of Dubois et al. (1956). Total organic phosphorus was estimated by the method of Ames (1966). Protein was estimated by the method of Lowry et al. (1951) with bovine serum albumin as standard. Mild acid hydrolysis was carried out in $0.1 \mathrm{M}$-formic acid, $\mathrm{pH} 2 \cdot 4$, for $1 \mathrm{~h}$ at $100^{\circ} \mathrm{C}$. Mild alkaline hydrolysis was carried out in $0.5 \mathrm{M}-\mathrm{NaOH}$ for $24 \mathrm{~h}$ at $20^{\circ} \mathrm{C}$.

Concanavalin A-Sepharose $4 B$ chromatography. The column (bed dimensions $0.5 \times 2.5 \mathrm{~cm}$ ) was equilibrated with $10 \mathrm{~mm}$-Tris/ $\mathrm{HCl}$ buffer, $\mathrm{pH} 7 \cdot 2$, containing $10 \mathrm{~mm}-\mathrm{MnCl}_{2}, 10 \mathrm{mM}-\mathrm{MgCl}_{2}$ and $10 \mathrm{mM}-\mathrm{CaCl}_{2}$. Fractions in this buffer were allowed to equilibrate with the column for $1 \mathrm{~h}$ at $20^{\circ} \mathrm{C}$. The column was eluted with the equilibration buffer to yield the unbound fraction and then with a gradient of 0 to $50 \mathrm{~mm}-\alpha$-methyl mannoside in the same buffer to yield the bound fraction. 


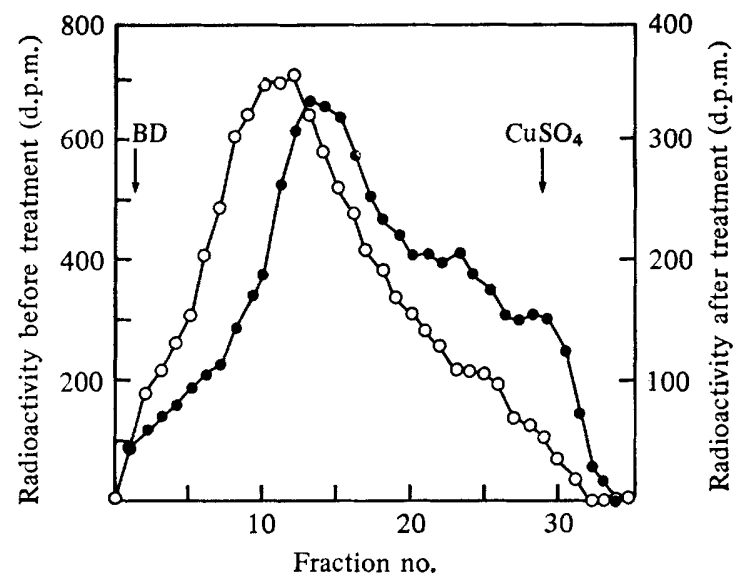

Fig. 2. Sephadex G-150 gel filtration of the high molecular weight fraction of race 0 grown in medium A (carbohydrate labelled exclusively) before $(O)$ and after (O) treatment with $0.5 \mathrm{mg}$ pronase $\mathrm{ml}^{-1}$ (Sigma; $24 \mathrm{~h}$ at $24^{\circ} \mathrm{C}, \mathrm{pH} \mathrm{7.0}$ ). The column was equilibrated and eluted with $0.05 \mathrm{M}$ -

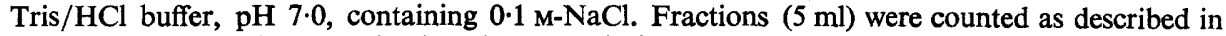
Methods. The Blue Dextran (BD) and $\mathrm{CuSO}_{4}$ elution volumes are shown.

\section{RESULTS}

The protocol for the fractionation of culture filtrates is shown in Fig. 1. Analyses of the carbohydrate and amino acid compositions of the high molecular weight fraction of filtrates of medium A showed that the carbohydrate moieties were labelled exclusively from D-[U- $\left.{ }^{14} \mathrm{C}\right]$ glucose and that amino acids were unlabelled. The specific activities of the different neutral sugars were identical under the labelling conditions employed. The high molecular weight fraction from all three races contained D-galactose, D-glucose and D-mannose as major constituents with much smaller amounts of D-glucuronic acid, D-glucosamine and D-galactosamine.

Gel filtration of the high molecular weight fraction on Sephadex G-150 equilibrated and eluted with $0.05 \mathrm{M}-\mathrm{Tris} / \mathrm{HCl}$ buffer, $\mathrm{pH} 7 \cdot 0$, containing $0 \cdot 1 \mathrm{M}-\mathrm{NaCl}$, showed a disperse peak of carbohydrate at an estimated molecular weight of 70000 (Fig. 2). After treatment of this fraction with pronase, the carbohydrate-containing material was eluted from the column in a larger volume (Fig. 2) giving preliminary evidence that this carbohydrate was covalently bound to protein in a glycoprotein or glycopeptide. Similar results were found for all three races.

\section{Ion-exchange chromatography of the high molecular weight fraction}

Although this fraction eluted as a single, though disperse, peak through Sephadex G-150, ion-exchange chromatography on DEAE-cellulose resolved it into several components of

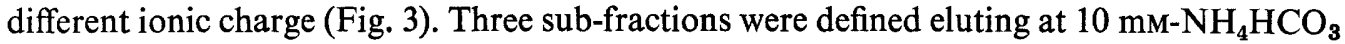
(fraction I), 10 to $100 \mathrm{~mm}-\mathrm{NH}_{4} \mathrm{HCO}_{3}$ (fraction II) and 100 to $500 \mathrm{~mm}-\mathrm{NH}_{4} \mathrm{HCO}_{3}$ (fraction III). The distribution of carbohydrate, protein and phosphate and the sugar analyses of these fractions from medium $A$ are shown in Tables 1 and 2. Fractions I and II each contained little protein and approximately one-third of the total carbohydrate. The molar ratio of phosphate to carbohydrate residues increased from fraction I to fraction III in all races. Treatment with pronase did not affect the distribution of carbohydrate between these fractions indicating that the degree of phosphorylation of carbohydrate moieties may have been responsible for the heterogeneity on ion-exchange chromatography. 


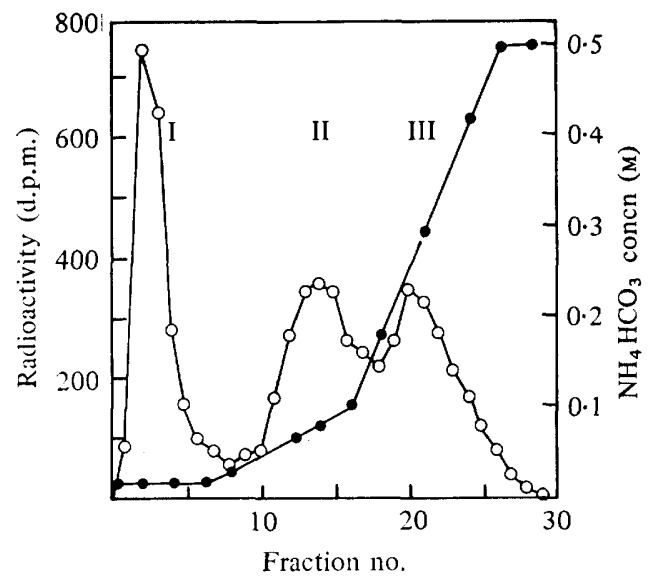

Fig. 3. Ion-exchange chromatography of the high molecular weight fraction of race 0 on DEAEcellulose at $\mathrm{pH} 7 \cdot 8$. The column $(1 \cdot 5 \times 6 \mathrm{~cm})$ was equilibrated with $10 \mathrm{~mm}-\mathrm{NH}_{4} \mathrm{HCO}_{3}$, then eluted successively with $10 \mathrm{mM}-\mathrm{NH}_{4} \mathrm{HCO}_{3}\left(30 \mathrm{ml}\right.$ ), a gradient of 10 to $100 \mathrm{~mm}-\mathrm{NH}_{4} \mathrm{HCO}_{3}$ (total gradient volume $50 \mathrm{ml}$ ) and a gradient of 100 to $500 \mathrm{~mm}-\mathrm{NH}_{4} \mathrm{HCO}_{3}$ (total gradient volume $50 \mathrm{ml}$ ). Fractions $(5 \mathrm{ml})$ were counted as described in Methods. $\mathrm{O}$, Radioactivity; $\mathrm{O}, \mathrm{NH}_{4} \mathrm{HCO}_{3}$ concentration (estimated conductimetrically).

Table 1. Distribution of carbohydrate, protein and phosphate amongst fractions $I, I I$ and III (see Fig. 1) of culture filtrates of races 0, 4 and 1.2.3. (medium A)

The amounts of protein and carbohydrate in each fraction are given as percentages of the total present in the high molecular weight fraction. The amount of phosphate is given as the molar ratio of phosphate to sugar residues as glucose equivalents.

\begin{tabular}{clccc}
\multirow{2}{*}{ Fraction } & & \multicolumn{3}{c}{ Race of $F$. fulva } \\
\cline { 3 - 5 } I & Protein & $11 \cdot 0$ & 4 & 1.2 .3$. \\
& Carbohydrate & $31 \cdot 2$ & $31 \cdot 6$ & $10 \cdot 0$ \\
II & Phosphate & $1: 81$ & $1: 80$ & $38 \cdot 1$ \\
& Protein & $11 \cdot 8$ & $10 \cdot 9$ & $11 \cdot 1$ \\
III & Carbohydrate & $30 \cdot 0$ & $36 \cdot 7$ & $44 \cdot 6$ \\
& Phosphate & $1: 34$ & $1: 30$ & $1: 32$ \\
& Protein & $77 \cdot 2$ & $78 \cdot 8$ & $78 \cdot 9$ \\
Total in & Carbohydrate & $38 \cdot 8$ & $31 \cdot 7$ & $17 \cdot 3$ \\
high mol. wt & Phosphate & $1: 17$ & $1: 17$ & $1: 18$ \\
fraction $(\mu \mathrm{g})$ & Carbohydrate & 2233 & 2102 & 1940 \\
& & 4251 & 5043 & 4413
\end{tabular}

Concanavalin A-Sepharose $4 B$ chromatography of fraction I

Concanavalin A-Sepharose 4B divided fraction I into a fraction which did not bind to, or had only a low affinity for, the column (fraction IA) and a fraction which bound to the column but which could be eluted with $\alpha$-methyl mannoside (fraction IB) (Fig. 4). When the unbound fraction was re-applied to the column, none of the radioactivity bound. Fractions IA and IB had very different carbohydrate compositions (Table 3) but both contained small amounts of protein (approximately 10\%). Fractions II and III could be similarly divided by this technique (data not shown). The sugar compositions of fractions from culture filtrates of fungus grown in medium B differed qualitatively from those found in glycerol-grown cultures, but equivalent fractions from all three races were similar (Tables 4 and 5). 
Table 2. Sugar compositions of fractions I, II and III (see Fig. 1) of culture filtrates of races 0,4 and 1.2.3. (medium $A$ )

The amount of each sugar in a fraction is given as a percentage of the total radioactivity (d.p.m.) in the sugars in that fraction.

Percentage of total radioactive sugar

\begin{tabular}{|c|c|c|c|c|c|c|c|c|}
\hline \multicolumn{3}{|c|}{ Fraction I } & \multicolumn{3}{|c|}{ Fraction II } & \multicolumn{3}{|c|}{ Fraction III } \\
\hline 0 & 4 & 1.2.3. & $\mathbf{0}$ & 4 & 1.2.3. & 0 & 4 & 1.2 .3 \\
\hline $1 \cdot 0$ & $1 \cdot 0$ & 0.7 & $2 \cdot 0$ & $1 \cdot 1$ & $2 \cdot 0$ & $0 \cdot 2$ & trace & trace \\
\hline $5 \cdot 1$ & 0.5 & trace & 6.8 & 0.8 & trace & $5 \cdot 0$ & trace & trace \\
\hline trace & 0.5 & trace & trace & trace & $4 \cdot 6$ & trace & trace & trace \\
\hline $7 \cdot 5$ & $14 \cdot 0$ & $16 \cdot 3$ & $17 \cdot 4$ & $19 \cdot 3$ & $22 \cdot 3$ & $15 \cdot 3$ & $25 \cdot 2$ & $30 \cdot 7$ \\
\hline $7 \cdot 0$ & $13 \cdot 2$ & $13 \cdot 9$ & $9 \cdot 2$ & $10 \cdot 1$ & $3 \cdot 6$ & $10 \cdot 5$ & $14 \cdot 2$ & $14 \cdot 9$ \\
\hline $79 \cdot 4$ & $70 \cdot 8$ & $69 \cdot 1$ & $64 \cdot 6$ & $68 \cdot 7$ & $67 \cdot 5$ & $69 \cdot 0$ & $60 \cdot 6$ & $54 \cdot 4$ \\
\hline
\end{tabular}

Total

radioactivity

$\begin{array}{llllllllll}\text { (d.p.m.) } & 1667 & 2043 & 3102 & 1328 & 4132 & 2205 & 1396 & 2990 & 1994\end{array}$

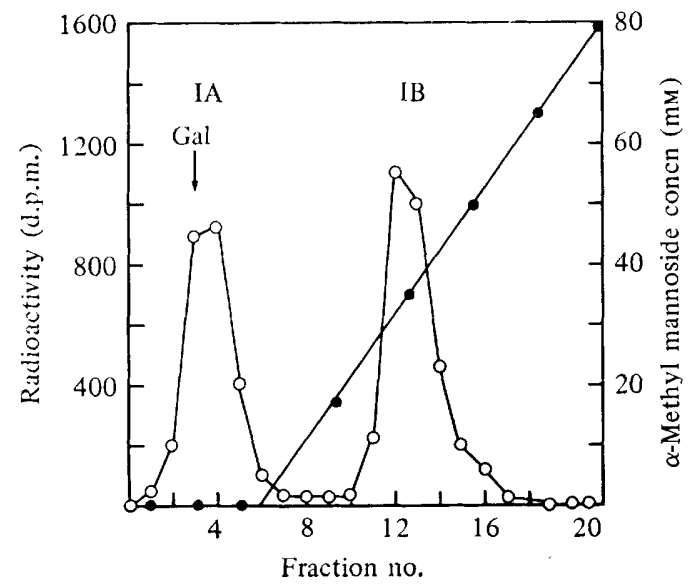

Fig. 4. Concanavalin A-Sepharose 4B affinity chromatography of fraction I of race 1.2.3. (carbohydrate was labelled exclusively in this fraction from medium A). $\bigcirc$, Radioactivity; $\mathbf{O}$, $\alpha$-methyl mannoside concentration, estimated by the method of Dubois et al. (1956). The elution position of galactose (unbound) is shown.

These results suggest that $F$. fulva synthesizes a family of polymers which differ in their detailed carbohydrate compositions and in the degree to which they are phosphorylated. All of the derived fractions probably contain a population of molecules of similar, but not identical, characteristics.

\section{Nature of phosphorus in fractions $I, I I$ and III}

Acid phosphatase failed to release inorganic phosphate from unlabelled or ${ }^{32} \mathrm{P}$-labelled polymers unless they were previously treated with phosphodiesterase or mild acid, indicating that the phosphorus was probably in a diester form in the polymers. Enzyme treatments were carried out under the conditions of San Blas \& Cunningham (1974). 
Table 3. Sugar compositions of fractions IA and IB (see Fig. 1) of culture filtrates of races 0,4 and 1.2.3. (medium $A$ )

The amount of each sugar in a fraction is given as a percentage of the total radioactivity (d.p.m.) in the sugars in that fraction.

Percentage of total radioactive sugar

\begin{tabular}{|c|c|c|c|c|c|c|}
\hline \multirow[b]{2}{*}{ Sugar } & \multicolumn{3}{|c|}{ Fraction IA } & \multicolumn{3}{|c|}{ Fraction IB } \\
\hline & 0 & 4 & 1.2 .3 & 0 & 4 & 1.2 .3 \\
\hline $\begin{array}{l}\text { GlcA } \\
\text { GalN }\end{array}$ & $1 \cdot 0$ & trace & $0 \cdot 7$ & 1.0 & trace & trace \\
\hline GalN & trace & trace & trace & 0.2 & trace & trace \\
\hline GlcN & trace & trace & trace & 0.2 & trace & trace \\
\hline Gal & $10 \cdot 0$ & $10 \cdot 2$ & $8 \cdot 3$ & $9 \cdot 4$ & $12 \cdot 3$ & $9 \cdot 5$ \\
\hline Glc & $30 \cdot 3$ & 32.4 & $28 \cdot 8$ & $10 \cdot 5$ & $4 \cdot 0$ & $5 \cdot 3$ \\
\hline Man & $58 \cdot 7$ & $57 \cdot 4$ & $62 \cdot 2$ & $78 \cdot 7$ & $83 \cdot 7$ & $85 \cdot 2$ \\
\hline $\begin{array}{c}\text { Total } \\
\text { radioactivity } \\
\text { (d.p.m.) }\end{array}$ & 4 & 8186 & 6268 & 5664 & 5980 & 2018 \\
\hline $\begin{array}{l}\text { Total } \\
\text { radioactivity } \\
\text { (\% radio- } \\
\text { activity in } \\
\text { fraction I) }\end{array}$ & $40 \cdot 9$ & 39.9 & $54 \cdot 4$ & $59 \cdot 1$ & $60 \cdot 1$ & $45 \cdot 6$ \\
\hline
\end{tabular}

Table 4. Sugar compositions of fractions I, II and III (see Fig. 1) of culture filtrates of races 0,4 and 1.2 .3 . (medium $B$ )

The amount of each sugar in a fraction is given as a percentage of the total radioactivity (d.p.m.) in the sugars in that fraction.

Percentage of total radioactive sugar

\begin{tabular}{|c|c|c|c|c|c|c|c|c|c|}
\hline \multirow[b]{2}{*}{ Sugar } & \multicolumn{3}{|c|}{ Fraction I } & \multicolumn{3}{|c|}{ Fraction II } & \multicolumn{3}{|c|}{ Fraction III } \\
\hline & 0 & 4 & 1.2 .3 & 0 & 4 & 1.2 .3 & 0 & 4 & 1.2.3. \\
\hline $\begin{array}{l}\text { GlcA } \\
\text { GaiN } \\
\text { GlcN } \\
\text { Gal } \\
\text { Glc } \\
\text { Man }\end{array}$ & $\begin{array}{c}1.5 \\
\text { trace } \\
0.6 \\
21.0 \\
23.3 \\
53.6\end{array}$ & $\begin{array}{c}2 \cdot 1 \\
\text { trace } \\
0 \cdot 4 \\
21 \cdot 1 \\
33 \cdot 2 \\
43 \cdot 2\end{array}$ & $\begin{array}{c}1 \cdot 7 \\
\text { trace } \\
0 \cdot 4 \\
18 \cdot 8 \\
28 \cdot 4 \\
50 \cdot 7\end{array}$ & $\begin{array}{c}2.5 \\
\text { trace } \\
0.3 \\
32 \cdot 3 \\
5 \cdot 0 \\
59 \cdot 9\end{array}$ & $\begin{array}{c}3 \cdot 3 \\
\text { trace } \\
0 \cdot 2 \\
36 \cdot 2 \\
4 \cdot 6 \\
55 \cdot 7\end{array}$ & $\begin{array}{c}2 \cdot 8 \\
\text { trace } \\
0 \cdot 3 \\
31 \cdot 2 \\
6 \cdot 7 \\
59 \cdot 0\end{array}$ & $\begin{array}{c}2 \cdot 0 \\
\text { trace } \\
0 \cdot 1 \\
26 \cdot 2 \\
6 \cdot 0 \\
65 \cdot 7\end{array}$ & $\begin{array}{c}3.2 \\
\text { trace } \\
\text { trace } \\
47 \cdot 5 \\
7 \cdot 5 \\
41.8\end{array}$ & $\begin{array}{c}2 \cdot 1 \\
\text { trace } \\
0 \cdot 1 \\
41 \cdot 6 \\
7 \cdot 0 \\
49 \cdot 2\end{array}$ \\
\hline $\begin{array}{r}\text { (dioactivi } \\
\text { (d.p.m.) }\end{array}$ & 20242 & 27143 & 21003 & 24130 & 53977 & 77130 & 14177 & 15408 & 16903 \\
\hline
\end{tabular}

\section{Mild acid treatment of fractions}

Mild acid treatment of fractions failed to release inorganic phosphate but did release monomeric sugars as determined by Bio-Gel P-2 chromatography against standards. All fractions from medium A showed similar behaviour although the degree of degradation varied between 8 and $14 \%$ of the total carbohydrate in the fraction. Carbohydrate analysis of the monomeric fraction showed that it was largely $(90 \%) \mathrm{D}$-galactose. The amount of sugar released is too great to be accounted for by hydrolysis solely of phosphodiester bonds and this acid lability is circumstantial evidence for the presence of galactofuranosyl residues in the polymers in the fractions. This treatment did not remove all of the galactose from the polymer. Although acid treatment led to a shift of the elution profile on Sephadex G-150, the polymer was not broken down into fragments of much smaller size indicating that the galactofuranosyl residues were not internal. Fractions from medium B showed no such 
Table 5. Sugar compositions of fractions IA and IB (see Fig. 1) of culture filtrates of races 0,4 and 1.2.3. (medium $B$ )

The amount of each sugar in a fraction is given as a percentage of the total radioactivity (d.p.m.) in the sugars of that fraction.

Percentage of total radioactive sugar

\begin{tabular}{|c|c|c|c|c|c|c|}
\hline \multirow[b]{2}{*}{ Sugar } & \multicolumn{3}{|c|}{ Fraction IA } & \multicolumn{3}{|c|}{ Fraction IB } \\
\hline & 0 & 4 & 1.2.3. & 0 & 4 & 1.2.3. \\
\hline GlcA & $1 \cdot 9$ & $2 \cdot 0$ & $1 \cdot 3$ & trace & $1 \cdot 0$ & $1 \cdot 8$ \\
\hline GalN & trace & trace & trace & trace & trace & trace \\
\hline GlcN & trace & trace & trace & trace & trace & trace \\
\hline Gal & $21 \cdot 2$ & $20 \cdot 4$ & $19 \cdot 4$ & $25 \cdot 3$ & $25 \cdot 6$ & $21 \cdot 5$ \\
\hline Glc & $45 \cdot 0$ & $47 \cdot 1$ & $50 \cdot 0$ & $8 \cdot 4$ & $9 \cdot 0$ & $10 \cdot 0$ \\
\hline Man & $31 \cdot 9$ & $30 \cdot 5$ & $29 \cdot 3$ & $66 \cdot 3$ & $64 \cdot 4$ & $66 \cdot 7$ \\
\hline $\begin{array}{c}\text { Total } \\
\text { radioactivity } \\
\text { (d.p.m.) }\end{array}$ & 5600 & 4523 & 6011 & 2440 & 1970 & 4131 \\
\hline
\end{tabular}

acid labile galactose; the degree of degradation was small (less than $3 \%$ ) and could probably be accounted for by the hydrolysis of phosphodiester bonds. All races showed similar behaviour.

\section{Mild alkali treatment of fractions}

Mild alkali treatment of all fractions from both media caused the release of oligosaccharides with a degree of polymerization of 1 to 4 as determined by Bio-Gel P-2 gel chromatography. These oligomers contained mannose as the sole sugar and accounted for up to $10 \%$ of the total carbohydrate in the fraction. Treatment with mild acid did not affect the degree of degradation on subsequent mild alkali treatment or vice versa.

\section{Nature of the protein in fractions $I$ and $I I$}

The protein moieties of fractions were labelled exclusively from L- $\left[\mathrm{U}-{ }^{14} \mathrm{C}\right]$ leucine. Fractionation through the protocol outlined in Fig. 1 confirmed that only a small percentage of the total protein in the high molecular weight fraction was associated with the carbohydrate in fractions I and II. This protein was considered to be covalently bound to the carbohydrate since carbohydrate and radioactivity could not be separated on glass-fibre paper electrophoresis at $\mathrm{pH} 2.0,3.5$ and 6.5 (data not shown). Mild alkali treatment, however, could separate the protein and carbohydrate. Gel chromatography showed that alkali splits the fraction I polymer into three distinct fragments: a high molecular weight polysaccharide which is eluted from Sephadex G-50 in the blue dextran void volume; a peptide which is eluted in the $\mathrm{CuSO}_{4}$ void volume of Sephadex G-50 but in the blue dextran void volume of Sephadex G-25; the oligosaccharides described above. The peptide portion must have a molecular weight of between 5000 and 10000 . The phosphate and the galactofuranosyl residues are associated with the polysaccharide portion of the molecules. The nature of the covalent linkages between the peptides and both the polysaccharide and oligosaccharide moieties is as yet unknown but may involve linkages to seryl or threonyl residues in the peptide, bonds which are capable of $\beta$-elimination in alkali (Neuberger et al., 1966). Similar features were found in all races and in fractions I and II from both media.

\section{Acetolysis of polysaccharide fragments after acid and alkali treatments}

The polysaccharide of fractions I, II and III from medium B which remained after mild acid and alkali treatments was subjected to acetolysis. This technique has been used to compare the structures of mannan polymers from different yeast species (Stewart \& Ballou, 


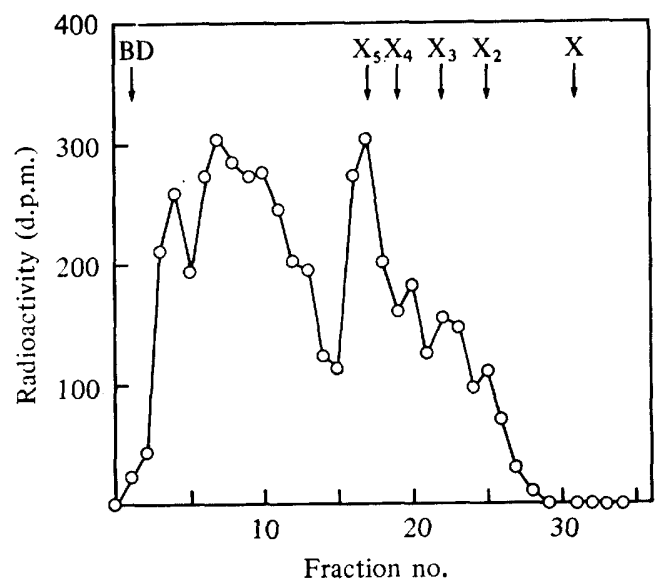

Fig. 5. Bio-Gel P-2 gel filtration of acetolysis products of the polysaccharide moiety of fraction I of race 1.2.3. remaining after mild acid and alkali treatments. Bed dimensions were $2 \times 96 \mathrm{~cm}$ and the column was eluted with distilled water; $5 \mathrm{ml}$ fractions were collected. The elution volumes of blue dextran $(B D)$, stachyose $\left(X_{4}\right)$, raffinose $\left(X_{3}\right)$, sucrose $\left(X_{2}\right)$ and mannose $(X)$ are shown. $X_{5}$ denotes the expected elution position of a pentasaccharide.

Table 6. Distribution of radioactivity between oligosaccharides derived by acetolysis of polysaccharide moieties of fractions I, II and III (see Fig. 1) of culture filtrates of races 0,4 and 1.2.3. (medium $B$ )

Polysaccharides were obtained by successive mild acid and mild alkali treatments of fractions I, II and III. The amount of sugar in a fraction is given as a percentage of the total radioactivity applied to the column (see Fig. 5 for details of chromatography).

\begin{tabular}{|c|c|c|c|c|c|c|c|c|c|}
\hline \multirow{3}{*}{$\begin{array}{c}\text { Oligo- } \\
\text { saccharide }\end{array}$} & \multicolumn{9}{|c|}{ Percentage of total radioactivity } \\
\hline & \multicolumn{3}{|c|}{ Fraction I } & \multicolumn{3}{|c|}{ Fraction II } & \multicolumn{3}{|c|}{ Fraction III } \\
\hline & 0 & 4 & 1.2.3. & 0 & 4 & 1.2 .3 & 0 & 4 & 1.2 .3$. \\
\hline$X \geqslant 6$ & $66 \cdot 8$ & $67 \cdot 2$ & $60 \cdot 7$ & $73 \cdot 1$ & $63 \cdot 4$ & $72 \cdot 2$ & $65 \cdot 4$ & $60 \cdot 9$ & $62 \cdot 2$ \\
\hline $\mathrm{X}_{5}$ & $18 \cdot 7$ & 23.5 & $16 \cdot 3$ & $26 \cdot 9$ & $36 \cdot 6$ & $27 \cdot 3$ & $33 \cdot 6$ & $32 \cdot 7$ & $37 \cdot 8$ \\
\hline$X_{4}$ & $4 \cdot 0$ & $3 \cdot 2$ & $11 \cdot 2$ & trace & - & 0.5 & 1.0 & $2 \cdot 5$ & trace \\
\hline $\mathrm{X}_{3}$ & trace & $4 \cdot 4$ & $8 \cdot 8$ & trace & - & - & - & - & - \\
\hline$X_{2}$ & $8 \cdot 7$ & 1.7 & 3.0 & - & - & - & - & 3.9 & - \\
\hline $\mathrm{X}$ & 1.8 & - & - & - & - & - & - & - & - \\
\hline $\begin{array}{l}\text { Total } \\
\text { adioactivity } \\
\text { (d.p.m.) }\end{array}$ & 2808 & 2937 & 4746 & 4186 & 9989 & 6967 & 2489 & 8496 & 4660 \\
\hline
\end{tabular}

1968). When de-acetylated oligosaccharides were chromatographed on Bio-Gel P-2, the fragmentation patterns obtained were similar, showing slight differences between fractions of the same race and between the same fractions of different races (Fig. 5, Table 6). The major identifiable oligomeric product of all races and fractions was eluted in the expected position of a pentasaccharide. Analysis of this fraction (Table 7) showed that the only sugars present were D-glucose, D-mannose and D-galactose. Although there was considerable diversity in the ratio of these sugars between fractions, the same fractions from different races were similar. Electrophoresis on glass-fibre paper in $0.05 \mathrm{M}$-borate buffer at $\mathrm{pH} 9.2$ showed that all fractions tested were heterogeneous, consisting of several molecular species. 
Table 7. Sugar compositions of pentasaccharide fragments derived by acetolysis of polysaccharide moieties of fractions I, II and III (see Fig. 1) of culture filtrates of races 0,4 and 1.2.3. (medium $B$ )

The amount of each sugar in a fraction is given as a percentage of the total radioactivity (d.p.m.) in the sugars in that fraction.

\begin{tabular}{|c|c|c|c|c|c|c|c|c|c|}
\hline \multirow[b]{3}{*}{ Sugar } & \multicolumn{9}{|c|}{ Percentage of total radioactive sugar } \\
\hline & \multicolumn{3}{|c|}{ Fraction I } & \multicolumn{3}{|c|}{ Fraction II } & \multicolumn{3}{|c|}{ Fraction III } \\
\hline & 0 & 4 & 1.2.3. & 0 & 4 & 1.2.3. & 0 & 4 & 1.2 .3 . \\
\hline Gal & $50 \cdot 1$ & $50 \cdot 3$ & $49 \cdot 5$ & $24 \cdot 1$ & $26 \cdot 1$ & $15 \cdot 3$ & $60 \cdot 6$ & $65 \cdot 5$ & $52 \cdot 5$ \\
\hline Glc & $19 \cdot 3$ & $18 \cdot 3$ & $20 \cdot 9$ & $15 \cdot 5$ & 14 . & $23 \cdot$ & $3 \cdot 0$ & $2 \cdot 6$ & \\
\hline Man & 30.6 & $31 \cdot 4$ & $29 \cdot 6$ & $60 \cdot 4$ & $59 \cdot 0$ & $61 \cdot 1$ & $36 \cdot 4$ & 31.9 & $44 \cdot 0$ \\
\hline \multicolumn{10}{|c|}{ Total } \\
\hline (d.p.m.) & 1910 & 3429 & 1010 & 2023 & 1119 & 920 & 1994 & 2328 & 896 \\
\hline
\end{tabular}

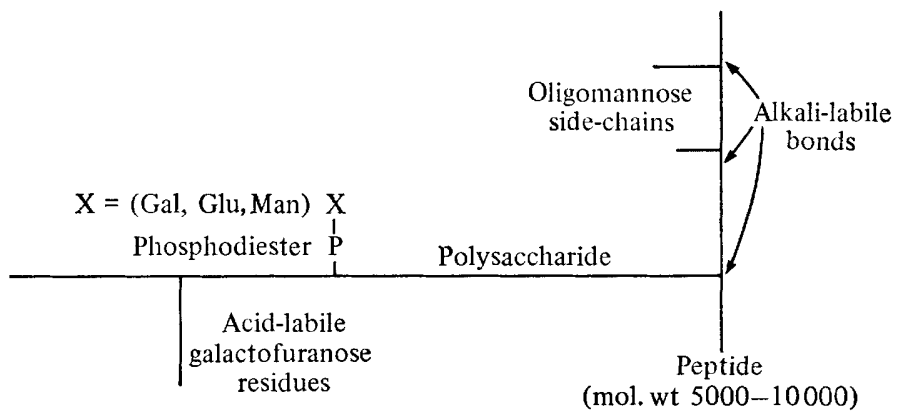

Fig. 6. Schematic representation of the possible organization of peptide, carbohydrate and phosphate moieties in the glycopeptide of $F$. fulva. The degree of degradation achieved with mild alkali indicates that there is probably more than one oligomannose chain for each polysaccharide in the polymer.

\section{DISCUSSION}

The results demonstrate that culture filtrates of several races of $F$. fulva contain a family of glycopeptide polymers of disperse molecular weight and composition. The degradative data are consistent with the generalized structure for these polymers shown schematically in Fig. 6. Polymers from different fractions differ in their detailed carbohydrate composition and degree of phosphorylation (and hence charge). The proposed structure is similar to that suggested for the secreted peptidophosphogalactomannan of Penicillium charlesii (Gander et al., 1974; Rick et al., 1974). Small differences between fungal races are found in the fragmentation patterns on acetolysis. The relationship (if any) of these differences to the differences in genotype defined by avirulence on tomato cultivars is not known. Differences in culture conditions lead to differences in the sugar composition of the polymers and also in the presence or absence of galactofuranosyl residues. The glycopeptides may derive from turnover of cell wall polymers as similar molecules may be extracted from the walls of $F$. fulva by treatment with water at $120^{\circ} \mathrm{C}$ (J. M. Dow, unpublished results).

Fractions I, II, IA and IB from all races caused a rapid leakage of electrolytes from isolated leaf mesophyll cells of tomato. These effects and their possible rôle in the hostphytopathogen interaction have been described elsewhere (Dow \& Callow, 1979). 
The authors wish to thank Dr A. Kaars Sijpesteijn, Dr N. Hubbeling and Miss Ir. I. W. Boukema for providing the races of Fulvia fulva. The work has been financed by a grant from the Agricultural Research Council.

\section{REFERENCES}

Albersheim, P. \& Anderson-Prouty, A. J. (1975). Carbohydrates, proteins, cell surfaces and the biochemistry of pathogenesis. Annual Review of Plant Physiology 26, 31-52.

AMEs, B. N. (1966). Assay of inorganic phosphate, total phosphate and phosphatases. Methods in Enzymology 8, 115-118.

Ayers, A. R., Ebel, J., Finelli, F., Berger, N. \& AlbersheIM, P. (1976a). Host-pathogen interactions. IX. Quantitative assays of elicitor activity and characterisation of the elicitor present in the extracellular medium of cultures of Phytophthora megasperma var. sojae. Plant Physiology 57, 751759.

Ayers, A. R., Ebel, J., Valent, B. \& Albersherm, P. (1976b). Host-pathogen interactions. X. Fractionation and biological activity of an elicitor isolated from the mycelial walls of Phytophthora megasperma var. sojae. Plant Physiology 57, 760765.

Ayers, A. R., Ebel, J., Valent, B. \& Albersheim, P. $(1976 c)$. Host-pathogen interactions. XI. Composition and structure of wall-release elicitor fractions. Plant Physiology 57, 766-774.

BARTNICKI-GARCIA, S. (1968). Cell wall chemistry, morphogenesis and taxonomy of fungi. Annual Review of Microbiology 22, 88-108.

Callow, J. A. (1977). Recognition, resistance and the role of plant lectins in host-parasite interactions. In Advances in Botanical Research, vol. 4, pp. 1-49. Edited by R. D. Preston \& H.W. Woolhouse. London \& New York: Academic Press.

Dow, J. M. \& Callow, J. A. (1979). The leakage of electrolytes from isolated leaf mesophyll cells of tomato induced by glycopeptides from culture filtrates of Fulvia fulvum (Cooke) Ciferri (syn. Cladosporium fulvum). Physiological Plant Patho$\log y$ 15, (in the Press).

Dow, J. M. \& RUBERY, P. H. (1977). Chemical fractionation of the cell walls of mycelial and yeast-like forms of Mucor rouxii: a comparative study of the polysaccharide and glycoprotein components. Journal of General Microbiology 99, 29-41.

Dubois, M., Gilles, K. A., Hamilton, J. K., Rebers, P. A. \& SMith, F. (1956). Colorimetric method for determination of sugars and related substances. Analytical Chemistry 28, 350-356.

GANDER, J. E. (1974). Fungal cell wall glycoproteins and peptido-polysaccharides Annual Review of Microbiology 28, 103-119.
Gander, J. E., Jentoft, N. H., Drewes, L. R. \& RICK, P. D. (1974). The 5-O- $\beta$-D-galactofuranosylcontaining exocellular glycopeptide of Penicillium charlesii. Characterization of the phosphogalactomannan. Journal of Biological Chemisty 249, 2063-2072.

KEEN, N. T. (1975). Specific elicitors of plant phytoalexins production: determinants of race specificity in pathogens? Science 187, 74-75.

Lowry, O. H., Rosebrough, N. J., Farr, A. L. \& Randall, R. J. (1951). Protein measurement with the Folin phenol reagent. Journal of Biological Chemistry 193, 265-275.

Neuberger, A., Gottschalk, A. \& Marshall, R. D. (1966). The Glycoproteins, vol. 5, pp. 273285. Edited by A. Gottschalk. London \& New York: Academic Press.

RICK, P. D., Drewes, L. R. \& GANDER, J. E. (1974). The $5-O-\beta$-D-galactofuranosyl-containing exocellular glycopeptide of Penicillium charlesii. Occurrence of ethanolamine and partial characterization of the peptide portion and the carbohydratepeptide linkage. Journal of Biological Chemistry 249, 2073-2078.

San Blas, G. \& Cunningham, W. L. (1974). Structure of cell wall and exocellular mannans from the yeast Hansenula holstii. 1. Mannans produced in phosphate-containing medium. Biochimica et biophysica acta 354, 233-246.

Stekoli, M. \& West, C. A. (1978). Purification and properties of an elicitor of castor bean phytoalexin from culture filtrates of the fungus Rhizopus stolonifer. Plant Physiology 61, 38-45.

Stewart, T. S. \& Ballou, C. E. (1968). A comparison of yeast mannans and phosphomannans by acetolysis. Biochemistry 7, 1855-1863.

Stewart, T. S., Mendershausen, P. B. \& Ballou, C. E. (1968). Preparation of a mannopentaose, mannohexaose and mannoheptaose from Saccharomyces cerevisiae mannan. Biochemistry 7 , 1843-1854.

Van Dijkman, A. \& KaARs Sijpesteijn, A. (1971). A biochemical mechanism for the gene-for-gene resistance of tomato to Cladosporium fulvum. Netherlands Journal of Plant Pathology 77, 14-24.

Van Dijkman, A. \& KaARs Sijpesteijn, A. (1973). Leakage of pre-absorbed ${ }^{32} \mathrm{P}$ from tomato leaf disks infiltrated with high molecular weight products of incompatible races of Cladosporium fulvum. Physiological Plant Pathology 3, 57-67. 